\title{
MENINGKATKAN KOMPETENSI SDM DI BUMD PDAM TIRTA PATRIOT KOTA BEKASI DALAM PEMBUATAN DOKUMENTASI SISTEM INFORMASI PELAYANAN PRIMA
}

\author{
Yessy Asri ${ }^{1}$, Dian Hartanti ${ }^{2}$, Dwina Kuswardani ${ }^{3}$, Emillia $^{4}$, Hendrianto Husada ${ }^{5}$, Hengki \\ Sikumbang ${ }^{6}$, M. Jafar Ely ${ }^{7}$ \\ ${ }^{1,2,3,6,7}$ S1 Teknik Informatika, STT-PLN Jakarta, ${ }^{4}$ S1 Teknik Mesin, STT-PLN Jakarta, ${ }^{5}$ S1 Teknik \\ Elektro, STT-PLN Jakarta \\ e-mail: ${ }^{1}$ yesfar2@gmail.com
}

\begin{abstract}
Abstrak
Perusahaan Daerah Air Minum (PDAM) Tirta Patriot Kota Bekasi sebagai penyedia jasa air bersih bagi area industri, area bisnis maupun pemukiman penduduk di wilayah operasional Tirta Patriot, meliputi Kabupaten Bekasi dan sebagian Kota Bekasi. Saat ini PDAM Tirta Patriot Kota Bekasi sudah memiliki Sistem Informasi Pelayanan Prima, yaitu sistem yang menangani mengenai pelayanan Pergudangan, Pelayanan Distribusi, dan Pelayanan Pengaduan. Sebuah Sistem Informasi pada hakekatnya adalah merupakan suatu sistem yang memiliki komponen-komponen atau sub sistem-sub sistem untuk menghasilkan informasi. Bisnis teknologi dunia saat ini didominasi oleh sektor teknologi informasi. Dalam menghadapi era globalisasi, persaingan akan semakin ketat, sehingga sangat dibutuhkan kebijakan-kebijakan dan aktivitas-aktivitas secara langsung yang dapat meningkatkan daya saing perusahaan di kemudian hari.Namun sampai saat ini, semua alur dari sistem informasi tersebut belum memiliki dokumentasi yang berbasiskan teknologi informasi. Metode yang digunakan untuk menjawab permasalahan atau mencapai tujuan kegiatan P2M adalah dengan mengadakan workshop. Dalam pembuatan dokumentasi sistem berbasiskan teknologi informasi Perusahaan Daerah Air Minum (PDAM) Tirta Patriot Kota Bekasi menggunaan perangkat lunak UML - Rational Rose 2000.
\end{abstract}

Kata kunci: Kompetensi, Sumber Daya Manusia, PDAM Tirta Patriot, Dokumentasi, Sistem Informasi Pelayanan Prima.

\section{Abstract}

Perusahaan Daerah Air Minum (PDAM) Tirta Patriot City of Bekasi as a provider of environmental services, business areas and residential areas in the operational area of Tirta Patriot, filling in Bekasi Regency and parts of Bekasi City. At present PDAM Tirta Patriot Kota Bekasi already has a Prime Service Information System, which is a system that handles Warehousing services, Distribution Marketing, and Complaint Services. An Information System is essentially a system that has components or sub-systems to produce information. The world technology business is currently 
published by the information technology sector. In the face of the globalization era, competition will be increasingly stringent, so that policies and interactions are specifically needed that can increase competitiveness in the future.. At present, all lines of information systems do not yet have information based on information technology. The method used to answer the problem or achieve the objectives of P2M activities is by holding a workshop. In making the system documentation that is used by the information Perusahaan Daerah Air Minum (PDAM) Tirta Patriot Kota Bekasi uses UML - Rational Rose 2000 software.

Keywords: Competence, Human Resources, PDAM Tirta Patriot, Documentation, Excellent Service Information System 


\section{PENDAhuluan}

Sumber Daya Manusia (SDM) mempunyai posisi sentral dalam mewujudkan kinerja pembangunan, yang menemptkan manusia dalam fungsinya sebagai resource pembangunan. Di dalam konteks ini harga dan nilai manusia ditentukan oleh relevansi konstruksinya pada proses produk. Kualitas manusia diprogramkan sedemikian agar dapat sesuai dengan tuntutan pembangunan atau tuntutan masyarakat. Eksistensi bangsa Indonesia ditengah percaturan era global sekarang, akan dipengaruhi kemampuan sumber daya manusia Indonesia, terutama yang bercirikan kemampuan penguasaan ilmu pengetahuan dan teknologi informasi.

Didasari besarnya tuntutan masyarakat terhadap kebutuhan air bersih, maka dibentuklah Satuan Pengelolaan Instalasi Air Bersih (SP-IPAS) dengan penanggung jawab H. Ir. Dudy Setiabudhi. Pendiriannya diawali dari proyek WEST JAVA URBAN DEVELOPMENT SECTOR PROJECT (WJUDSP) ADB LOAN 1384-INO tahun 2001-2003 dengan sumber dana dari pinjaman ADB, Pemerintah Pusat dan Pemerintah Kota Bekasi. Tujuannya adalah untuk menyediakan air bersih bagi masyarakat di daerah rawan air bersih.

Setelah proyek selesai dilaksanakan, pengelolaan hasil pembangunan diserahkan kepada Satuan Pengelola Instalasi Air Bersih (SP-IPAS) sesuai dengan SK. Walikota Bekasi Nomor 693/DTKP/X/2003. Pengelolaan yang cukup baik menjadikan SP-IPAS dipercaya sebagai penyedia layanan air bersih. Jumlah pelanggan yang terus bertambah menuntut pengembangan manajemen dan organisasi. Oleh karena itu, SP-IPAS disempurnakan menjadi Pengelola Instalasi Pengelolaan Air Teluk Buyung (PIPA TB) berdasarkan keputusan Walikota Nomor 71 Tahun 2004 dengan di Ketuai oleh H. Dadang Hidayat.

Manajemen perusahaan yang semakin baik menjadikan PIPA TB kian penting perannya di Kota Bekasi. Kemampuan memberikan sumbangan bagi PAD Kota Bekasi menjadi acuan penyempurnaan organisasi menuju PDAM Tirta Patriot Kota Bekasi melalui Peraturan Daerah Kota Bekasi Nomor 02 Tahun 2006. H. Dadang Hidayat untuk sementara menjabat sebagai Direktur sampai ditunjuk Direktur PDAM yang definitif. Tidak lama, akhirnya Walikota Bekasi menunjuk H. Syafei Muhamad sebagai Direktur PDAM Tirta Patriot Kota Bekasi yang definitif.

PDAM Tirta Patriot Kota Bekasi yang merupakan salah satu unit usaha milik daerah yang bergerak dalam distribusi air bersih bagi masyarakat umum. PDAM terdapat di setiap provinsi, kabupaten, dan kotamadya di seluruh Indonesia. PDAM merupakan perusahaan daerah sebagai sarana penyedia air bersih yang diawasi oleh aparat - aparat eksekutif maupun legislatif daerah. Perusahaan air minum yang dikelola secara modern sudah ada sejak tahun 2006. Terdapat beberapa divisi di PDAM Tirta Patriot Bekasi, salah satunya adalah LITBANG (Penelitian dan Pengembangan). Divisi ini bertanggung jawab dalam hal melaksanakan penelitian, evaluasi sistem dan prosedur operasional perusahaan; menyususun program pengembangan perusahaan jangka menengah dan panjang; melaksanakan evaluasi pengembangan perusahaan; melaksanakan tugastugas lain yang diberikan Direktur Utama sesuai dengan tugasnya; pengelolaan sumber daya teknologi informasi, serta divisi ini juga berkewajiban untuk melayanai berbagai macam permasalahan yang berhubungan dengan teknologi informasi. Untuk kegiatan pekerjaan sehari-hari, hampir setiap karyawan PDAM Kota Bekasi sudah menggunakan teknologi, antara lain untuk mengetik dokumen mencetak dokumen di komputer, absensi, dan masih banyak lainya, semua menggunakan teknologi. 
Seiring dengan berjalanya waktu, dimana semakin banyak permasalahan yang dialami oleh divisi LITBANG PDAM Kota Bekasi, seperti banyaknya aduan dari pelanggan mengenai pelayanan dalam penanganan permasalahan. Dengan kondisi yang terjadi diatas, maka saat ini PDAM Tirta Patriot Kota Bekasi sudah memiliki Sistem Informasi Pelayanan Prima, yaitu sistem yang menangani mengenai pelayanan Pergudangan, Pelayanan Distribusi, dan Pelayanan Pengaduan. Namun sampai saat ini, semua alur dari sistem informasi tersebut belum memiliki dokumentasi yang berbasiskan teknologi informasi.

Pengabdian Kepada Masyarakat ini akan mengarahkan berupa suatu pelatihan kepada SDM divisi LITBANG PDAM Tirta Patriot Kota Bekasi mengenai analisis pada Sistem Informasi Pelayanan Prima PDAM Kota Bekasi dan penggunaan perangkat lunak UML - Rational Rose 2000 dalam pembuatan dokumentasi sistem berbasiskan teknologi informasi.

\section{METODE}

Metode yang digunakan untuk menjawab permasalahan atau mencapai tujuan kegiatan P2M adalah dengan workshop melalui tahapan sebagai berikut:

\subsection{Persiapan}

Persiapan dilakukan dengan mengadakan kesepakatan kerjasama dengan mitra, yaitu antara Ketua Tim dan anggota P2M STT-PLN dengan Kasubag Divisi LitBang PDAM Tirta Patriot Kota Bekasi yaitu Bapak Bahrul Alam, ST. Selanjutnya mengundang para staff divisi LitBang PDAM Tirta Patriot Kota Bekasi untuk mengikuti workshop, mempersiapkan Materi, dan tempat pelatihan yaitu di ruang kerja staff divisi LitBang yang berada di Gedung Utama Lantai 2 Kantor PDAM Tirta Patriot Kota Bekasi.

\subsection{Pelaksanaan}

Pelaksanaan workshop di ruang kerja staff divisi LitBang yang berada di Gedung Utama Lantai 2 Kantor PDAM Tirta Patriot Kota Bekasi. Workshop diawali dengan penyampaian Materi yaitu berupa alur sistem informasi Pelayanan Prima sub Sistem Pengaduan Pelanggan PDAM Tirta Patriot Kota Bekasi yang diwakili oleh KasuBag divisi LitBang yaitu Bapak Achmad Arifin, Amd. Alur Sistem Informasi Pelayanan Prima Pengaduan Pelanggan terdiri dari beberapa alur, yaitu Pergantian Meter Air Pelanggan Umur Teknis, Pemasangan Sambungan Baru, Pergantian Pipa Persil Umur Teknis, Pemutusan Sambungan Pelanggan dan Pasang KembaliPLTS sangat fleksibel. Kegiatan ini diikuti oleh staff divisi LitBang yang terdiri dari Sep/uluh (10) orang. Dalam Praktik dan tugas mandiri ini peserta melakukan analisis terhadap alur sistem informasi pada Pelayanan Prima Pengaduan Pelanggan PDAM Tirta Patriot Kota Bekasi hingga perancangan alur sistem informasi dengan menggunakan aplikasi pemodelan visual Rational Rose 2000.

Pelaksanaan Workshop, sesuai dengan kesepakatan mitra dengan tim pelaksana pengabdian, dibutuhkan waktu minimum 20 jam yang dilaksanakan selama empat hari kerja, yaitu hari Kamis Jumat tanggal 5, 6, 26, dan 27 Juli 2018 mulai pukul 09.00 - 15.00 WIB. 
Materi Workshop adalah:

Langkah 1: Peserta pelatihan diberikan teori tentang konsep dasar sistem informasi, dasar-dasar analisis studi kelayakan, teknik perancangan sistem secara detail.

Langkah 2: Setelah mendapatkan teori tentang konsep dasar sistem informasi, dasar-dasar analisis studi kelayakan, teknik perancangan sistem secara detail, setiap peserta diminta untuk menjabarkan komponen-komponen dasar sebuah sistem informasi, karakteristik sistem informasi, dan tahapan perancangan sistem informasi secara detail.

Langkah 3: Setiap peserta secara mandiri dicoba untuk melakukan perancangan sistem informasi dengan mengambil satu dari studi kasus alur sistem informasi pada Pelayanan Prima yaitu "Pergantian Meter Air Pelanggan Umur Teknis".

Langkah 4: Setiap peserta secara mandiri mendapatkan teknik penggunaan alat dokumentasi hasil analisis dan perancangan sistem informasi dengan menggunakan aplikasi pemodelan visual UML - Rational Rose 2000.

Langkah 5: Setiap peserta secara mandiri melakukan praktek penggunaan aplikasi pemodelan visual UML - Rational Rose 2000.

\subsection{Pemantauan (monitoring)}

Pemantauan dilakukan oleh tim PKM STT-PLN yang berjumlah tujuh orang. Pelaksanaannya dilakukan selama empat hari. Pemantauan ini bertujuan untuk mengetahui kemajuan, berkelanjutan atau dari analisis dan perancangan sistem informasi Pelayanan Prima Pengaduan Pelanggan. Hal-hal yang dipantau diantaranya adalah aktivitas staff divisi LitBang PDAM Tirta Patriot Kota Bekasi dalam menganalisis dan merancang dokumentasi sistem informasi Pelayanan Prima, analisis dan perbaikan dari perancangan alur sistem informasinya, dan perbaikan-perbaikan dari hasil analisis dan perancangan yang dibuat.

\section{HASIL DAN PEMBAHASAN}

Peserta yang aktif adalah enam orang peserta dari sepuluh orang staff divisi LitBang PDAM Tirta Patriot Kota Bekasi, ketidakhadiran staff ini dikarenakan adanya tugas yang harus dikerjakan dan rapat penting lainnya.

Berikut salah satu alur sistem informasi pada Pelayanan Prima PDAM Tirta Patriot Kota Bekasi, Pergantian Meter Air Pelanggan Umur Teknis. 

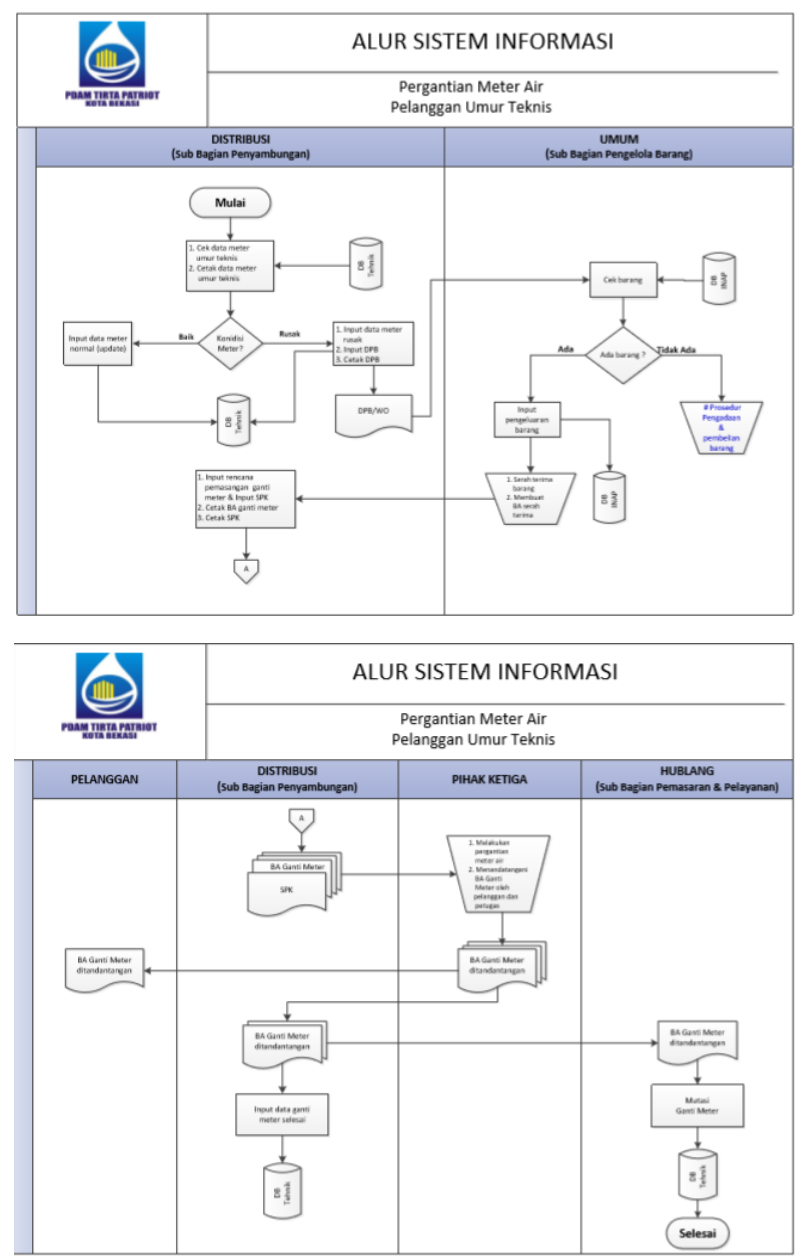

Gambar 1. Alur Sistem Informasi Pergantian Meter Air Pelanggan Umur Teknis

Siklus atau daur hidup pengembangan sistem tampak jika sistem yang sudah ada dikembangkan dan dioperasikan tidak relevan lagi atau sudah tidak mampu lagi mencapai tujuan yang ditentukan, sehingga dibutuhkan pengembangan sistem kembali untuk menyesuaikan dengan kondisi terbaru. Pengembangan sistem dapat berarti menyusun suatu sistem yang baru untuk menggantikan sistem yang lama secara keseluruhan atau memperbaiki sistem yang telah ada.

Perbaikan sistem atau penggantian sistem dapat dilihat dari dua faktor penyebab yaitu internal dan eksternal:

1. Faktor internal antara lain adanya permasalahan-permasalahan yang timbul di dalam sistem lama, pertumbuhan organisasi, instruksi top level manajemen serta untuk meraih kesempatan/isu-isu strategis yang menguntungkan.

2. Faktor eksternal antara lain berhubungan dengan batasan dan lingkungan tempat dimana sistem itu berjalan. Dalam satu lingkungan terdapat beberapa sistem berbeda yang cenderung saling mempengaruhi satu dengan lainnya. Jika satu sistem mengalami kemajuan otomatis akan mempengaruhi/bahkan memaksa sistem lain untuk berkembang. Selain itu peraturan dan kebijakan pemerintah yang berlaku juga berperan terhadapt perkembangan sistem. 
Hasil dari hasil analisis dan perancangan diagram use case dengan aplikasi Rational Rose 2000 dari alur sistem informasi Pelayanan Prima Pengaduan Pelanggan "Pergantian Meter Air Umur Teknis" dengan para staff divisi LitBang PDAM Tirta Patriot Kota Bekasi.

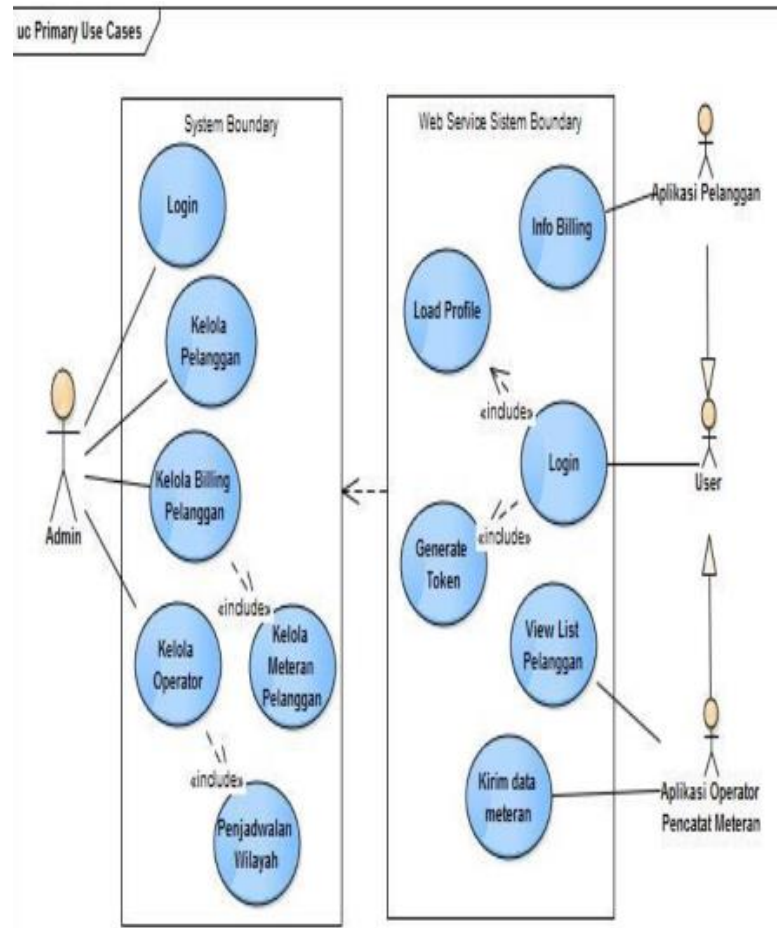

Gambar 2. Use Case Diagram Pergantian Meter Air Pelanggan Umur Teknis

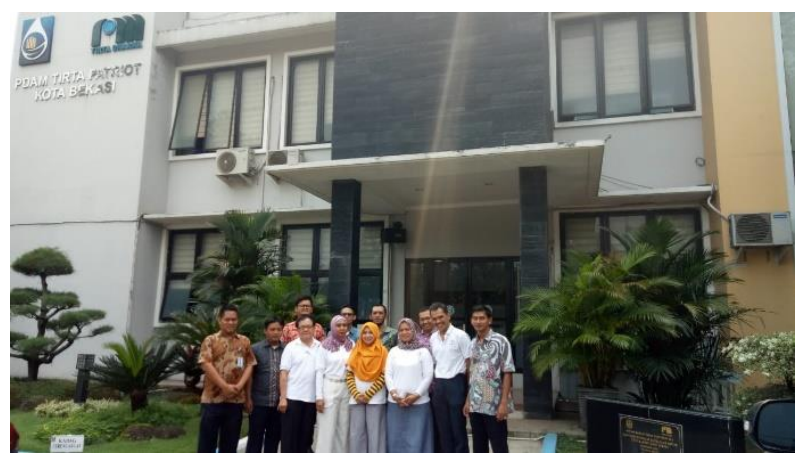

Gambar 3. Foto Bersama Dengan Divisi Litbang PDAM Tirta Patriot Kota Bekasi 


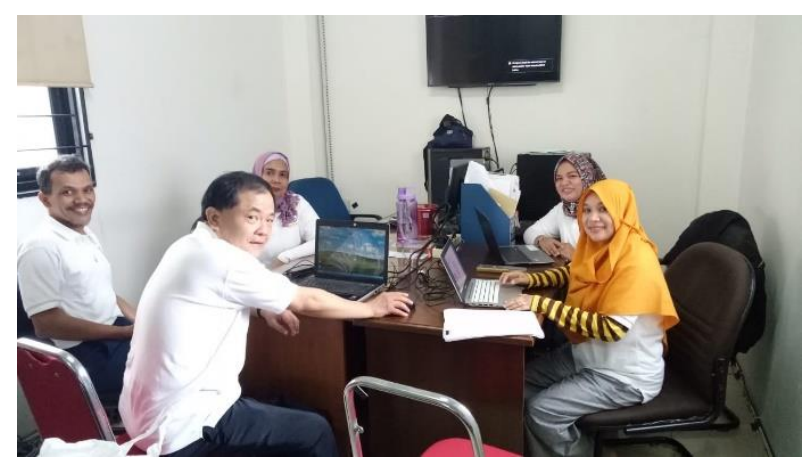

Gambar 4. Persiapan Workshop

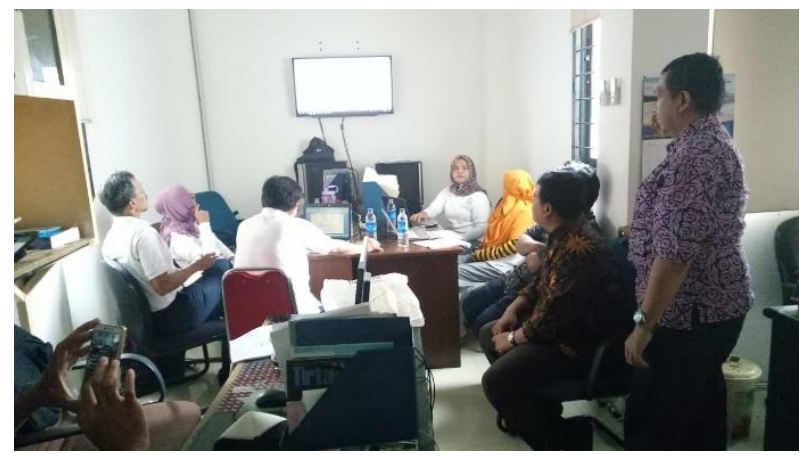

Gambar 5. Pelaksanaan Workshop

\section{KESIMPULAN}

Dari hasil proses program Pengabdian Pada Masyarakat (P2M) yang diselenggarakan oleh LPPM STT-PLN yang berjudul tentang "Meningkatkan Kompetensi SDM di Lingkungan BUMD PDAM Tirta Patriot Kota Bekasi Divisi LITBANG Dalam Pembuatan Dokumentasi Sistem Informasi Pelayanan Prima" sub sistem Pengaduan Pelanggan ini, maka dapat ditarik kesimpulan sebagai berikut:

1. Pengembangan sistem dapat berarti menyusun suatu sistem yang baru untuk menggantikan sistem yang lama secara keseluruhan atau memperbaiki sistem yang telah ada.

2. Sebuah sistem memiliki beberapa karakteristik, yaitu memiliki komponen-komponen (Components), mempunyai Batasan Sistem (Boundary), adanya Lingkungan Luar Sistem (Environment), memiliki Penghubung (Interface), adanya Masukan (INPUT), menghasilkan Keluaran (OUTPUT), memiliki Pengolah (PROSES), mempunyai Tujuan (Goal) \& Sasaran (Objective).

3. Sistem Informasi adalah sistem manusia atau mesin yang terpadu untuk menyajikan informasi guna mendukung fungsi operasi manajemen di dalam suatu organisasi, sistem yang disajikan dapat menggunakan HARDWARE dan SOFTWARE serta Prosedur dan Model manajemen dengan menggunakan sebuah DATABASE.

4. Rational Rose merupakan sebuah perangkat pemodelan secara visual yang memiliki banyak kemampuan (powerful) untuk pembentukan sistem berorientasi obyek yang menggunakan Unified Modeling Language (UML). 
5. Alur Sistem Informasi pada PDAM Tirta Patriot Kota Bekasi Pelayanan Prima sub sistem Pengaduan Pelanggan, diantaranya adalah Pergantian Meter Air Pelanggan Umur Teknis, Pemasangan Sambungan Baru, Pergantian Pipa Persil Umur Teknis, Pemutusan Sambungan Pelanggan dan Pasang KembaliPLTS sangat fleksibel.

\section{SARAN}

Perlu adanya kegiatan pengembangan alur sistem informasi pada sub sistem lainnya dalam menyusun suatu sistem yang baru untuk menggantikan sistem yang lama secara keseluruhan atau memperbaiki sistem yang telah ada.

\section{UCAPAN TERIMA KASIH}

Terimakasih disampaikan kepada Lembaga Penelitian dan Pengabdian Masyrakat (LPPM) STTPLN yang telah mendanai Pengabdian Kepada Masyarakat melalui Program Kemitraan Masyarakat (PKM).

\section{DAFTAR PUSTAKA}

[1] Al Fatta, Hanif. 2012. Analisis dan Perancangan Sistem Informasi. Yogyakarta: Andi.

[2] Fathansyah. 2012. Basis Data. Bandung: Informatika.

[3] Herdiansyah, Haris. 2013. Wawancara, Observasi, dan Focus Groups. Jakarta : Rajawali Pers.

[4] Kristanto, Andri. 2011. Perancangan Sistem Informasi dan Aplikasinya. Yogyakarta : Gave Media.

[5] Pratama, I Putu Agus Eka.2014. Sistem Informasi dan Implementasinya. Bandung : Informatika.

[6] Pressman, Roger S. 2012. Rekayasa Perangkat Lunak. Yogyakarta : Andi..

[7] Sukamto, Rosa A dan M Shalahudin. 2014. Rekayasa Perangkat Lunak Terstruktur dan Berorientasi Objek. Bandung : Informatika Bandung 